\title{
Fostering Narrative Post-writing through Authentic Designed Learning Objects
}

\author{
María C. Caro \\ Department of Foreign Languages and Cultures, Universidad de La Sabana, Bogotá, Colombia \\ Diana A. Parra \\ Department of Foreign Languages and Cultures, Universidad de La Sabana, Bogotá, Colombia
}

\begin{abstract}
One of the challenges language teachers face is how to engage learners to empower their writing skills. Teacher's feedback is a key feature when developing writing, but it seems not to be effective when learners remain having the same difficulties. It is imperative to examine pedagogical actions for motivating and tackling learners post writing difficulties. This action research study states a new alternative in which students autonomously learn and experience strategies to become better writers. The analysis focused on the influence that the process writing approach, focalized on the monitoring strategy of the post-writing stages, and the implementation of authentic designed learning objects (LOs) had on young adult learners' short narrative compositions. Outcomes indicate that students improved their writing since the tasks responded to their cognitive and affective profiles. Findings also suggested that the PRWRITE LOs clearly guided learners in the developmental process of writing. Students perceived those technological tools as interesting, applicable and motivating for their learning. This pedagogical experience promotes the design of innovative tools based on learners' needs and goals, which motivate and engage them in an improving process.
\end{abstract}

Index Terms — autonomy, awareness, learning object, process writing approach, writing strategies

\section{INTRODUCTION}

Developing writing skills is not always prioritized in language syllabi at educational institutions. To effectively foster this production skill, teachers should look for strategies and sometimes extra time for succeeding. Since the writing process involves complex cognitive operations, authors such as Flower and Hayes (1981) have described components and stages to help teachers guiding this process. From the cognitive process perspective, the important components of writing development are planning, drafting, revising, editing, and evaluating in a feedback loop, which can be completed by students autonomously. Understanding writing as a cognitive process means, as Zamel (1983) affirms, that writing is a "non-linear, exploratory, and generative process whereby writers discover and reformulate ideas as they attempt to approximate meaning" (as cited in Hyland, 2002, p.20). This cognitive writing process allows students to be responsible for their own tasks and requires them to continuously correct or pay attention to teacher's and/or peers' corrections in their writing.

This study integrates the use of technology as a writing skill development support. When implementing technology in the EFL classroom, learners' motivation is key. Dörnyei (1998) states that "the teacher skills in motivating learners should be seen as central to teaching effectiveness" (p.119). In this study, technology was also used by teachers as a motivational factor to enhance learners' interest for learning English as a foreign language (Castellano, 2016; Masaeli \& Chalak, 2016). However, using technology requires teachers to have certain technical abilities to create innovative learning materials. Designing materials, as opposed to using already designed materials (e.g. course books), means adjusting them to students' learning needs, styles, preferences, and interests, which can also integrate different kinds of resources (Kamariah, Husain, Atmowardoyo, \& Salija, 2018). LOs represent a new way to design innovative materials, since they are created with the purpose of supporting educational practices. They are "a new type of computer-based instruction which can be any digital resource and can be reused to support learning" (Willey, 2000, p.3).

\section{REVIEW OF LITERATURE}

Pedagogical interventions implemented as alternatives to tackle learners' difficulties in language learning have been the focus of interest of many researchers and teacher-researchers (Ariza, 2005; Lo \& Hyland, 2007; Baroudy, 2008). In the first place, this review explores the literature in regard to the approach selected to tackle learners writing difficulties; in the second place, it explores the theory and literature about the use of technology in the educational field, specifically the design of learning objects in the EFL classroom.

Process-Writing Approach (PWA)

Here in, writing is not only considered as a cognitive process, but also a problem-solving activity influenced by the task-environment (Tang, 2016). This writing model considers important features such as writer's goals, writing structuring processes (planning, drafting, revising, and editing), evaluation through feedback, and constant monitoring 
(Hyland, 2002). This model also considers the writer's experience, knowledge, rhetorical structure, and the audience. These elements become meaningful when designing engaging writing tasks for learners (Ellis, 2003). Ariza (2005) has demonstrated that the use of PWA helps learners generate ideas in the first stages of writing and its implementation creates a willingness to learn.

From the PWA approach, writing is a developmental process because learners explore and discover ideas to write (Raimes, 1983) and they are not evaluated on their final products but on their improvements during the process (Hyland 2002). The PWA has also proved to positively influence learners' writing skill and increase their motivation to write in the foreign language (Ariza, 2005, Zuniga \& Macias, 2006; Lo \& Hyland, 2007; Baroudy, 2008; Onozawa, 2010; and Vijaya \& Shahin 2016). In a step-by-step writing process, students are provided with opportunities to improve through constant feedback and become better writers (Zuniga \& Macias, 2006).

When developing PWA, the teacher's role is to be a guide and facilitator who provides learners with clear instructions and appropriate models (Ariza, 2005). This approach encourages teachers to help students develop viable strategies at each writing stage; these strategies empower learners with tools for them to improve, and gain knowledge and experience when writing (Zuniga and Macias, 2006). Teachers as motivators need to propose writing tasks, having in mind that learners' motivation is influenced by their feelings of control over the learning activities and their interest on it (Lo and Hyland, 2007).

\section{Computer-Assisted Language Learning (CALL)}

The fact that technology literacy increasingly becomes more necessary has influenced teachers to integrate computers as a tool in their pedagogical practice. CALL emerged as a way to direct the implementation of computers for pedagogical purposes, and activities developed with CALL are described to be interactive and to provide the presentation of information, guidance to the learner, practicing moments, and learning assessment. They also favor students' autonomous learning, allowing them to vary the amount of time taken in a learning activity, which normally depends on individual performance (Chapelle, 2008).

CALL opens different possibilities for improving different skills in the language learning process, but it tends to benefit writing development more directly because of its use in everyday communication. Interactions in most computer-mediated communication often occur through writing. According to Chapelle (2008), "written interaction helps direct learners' attention to important linguistic features" (p. 23), thus, learners increase their abilities for communicating effectively through writing.

\section{Virtual Learning Objects (VLO)}

Learning Objects (LOs) are a new computer-based instructional technology, defined as digital sources used to support learning (Wiley, 2000). LOs are also pedagogical sources that foster students' participation in their own knowledge construction and cognitive development. Thus, for the LOs design to be successfully used in a classroom, teachers should have certain technological skills and must consider several factors such as technological, epistemological, methodological, and visual requirements (Behar, Frozi, and Bernardi, 2008). It is also important to consider learners as the main component when building a LO. Aspects such as learners` role, knowledge, preferences, motivations, and performance should also be taken into consideration in the design process. Smith (2005) has figured out that in order to make LOs learner-centered and enhance their motivation, aspects such as learners' cognitive level, appropriate goal-setting, among others, may be considered.

LOs have become research instruments in different knowledge fields, author-researchers such as Behar, Frozi, and Bernardi (2008), Leal (2008), Díaz (2010), Watson (2010), Fallon, Janson, and Janson (2010), and Ramirez, (2009) have evinced advances in global and local stages in structure, design, and implementation of LOs.

LOs, as a learning support tool, are a way for learners to access to information and to develop activities independently and autonomously (Behar, Frozi and Bernardi, 2008). LOs have also been tools that provide students with a motivating and engaging learning experience since they have been linked to learning goals (Janson, 2010). Diaz (2010) found out that LOs stimulate learners to look for new ways to study and reinforce what they have learnt in the classroom. In the language teaching and learning field, LOs have also been explored and developed. Watson (2010) conducted a case study in which VLOs, organized in sets based on language skills, were developed to support face-toface language learning environments. Those LOs had a positive role in helping students learn since they had an explicit pedagogical design.

Many of the studies presented in this literature review have provided insights for implementing the PWA and designing LOs as strategies to strengthen and motivate learners' writing competences.

\section{METHODOLOGY}

\section{Participants and Curriculum}

Fourteen adult second language (L2) learners, between the ages of 17 and 35, coursing their second Adult Education first-cycle studies semester, in a higher education institution in Bogotá, Colombia, were involved in the study. Most of them have completed only high school or some vocational studies, and have had limited English instruction. All of them were, upon admission, placed at the A1 English level as described in the Common European Framework (CEFR, 2002).

According to the institution's English curriculum, these students were required to attend one four-hour classroom sessions and complete seven hours of independent learning each week. For this reason, the curriculum emphasizes oral 
production and oral comprehension in the face-to-face sessions and written production and written comprehension in the autonomous learning time. Students are expected to self-direct their learning (Merriam, 2001) regarding the tasks that relate reading and writing skills. The corresponding syllabus for the second semester of the English course requires students to develop narrative writing skills (Caro, 2014).

\section{Needs Analysis and Method}

This research project started with a needs analysis in which a problem in the writing performance of the target group was confirmed. Students presented difficulties when revising and editing their compositions during the post-writing stage, and as a result, they repeated errors in the final drafts of their compositions. A survey permitted their teacher to confirm her pedagogical concern on the problem. Students expressed their difficulties with writing, including the lack of work on their compositions after drafting them. Hence, this research project aimed to unveil how the implementation of the PWA and the PRWRITE LOs (the virtual learning object tool: Process Writing Learning Objects) might guide students to overcome these difficulties. Accordingly, this research attempted to examine how learners' short narrative compositions might change by implementing PWA revision and editing strategies and understand how students' autonomous actions were influenced by PRWRITE Los (Caro, 2014).

For this qualitative study, framed in an Action Research kind (Burns, 2010), the teacher-researcher selected the Grounded Theory method as the framework of analysis. Corbin and Strauss (2008) claim that this approach is developed through a systematical process of gathering and analyzing data. The analysis process requires researchers to review numerous times the data gathered, developing a cyclical analysis. Through the process of comparing, contrasting, interpreting, or connecting, researchers identified relevant information that led to answer the research questions.

\section{Data Collection Instruments}

During the pre-implementation stage, data was collected with a checklist which diagnosed strengths and weaknesses in student's narrative compositions. In the while-implementation stage, the same checklist was used to compare students' written performance and verify possible improvements. In the post-implementation stage, a survey was applied with the purpose of corroborating data (Appendix C).

The checklist was filled out with a check $(\boldsymbol{V})$ when the good use of the feature was displayed in the student's composition, and a cross (X) to refer to a wrong use of the aspect (Appendix A). Data collected was totaled per each student, based on how many checks and crosses he/she had. Afterwards, the researcher analyzed the quantitative checklist results based on the open coding procedure in which main tendencies were grouped and based on that, interpretations of the data were made. Predominant tendencies were identified after a process of comparing and contrasting the results. Finally, the tendencies were interpreted and qualitatively analyzed in a new chart (Caro, 2014).

For the second instrument, the researcher followed the same procedure, but this time it was done based on the analysis of students' narrative compositions during the editing stage of the PWA. The checklist was filled in and the data collected was totaled (Appendix A). Afterwards, a chart was filled in with both the checklist results from the diagnosis narrative compositions and the results from the editing stage of the writing process. Based on the open coding procedure these results were compared and analyzed. Improvement in students' difficulties and possible changes on their writing strengths in each one of the aspects are interpreted and determined (Appendix B) (Caro, 2014).

\section{Data Collection Procedure}

In the implementation period, students developed tasks that focused their attention on the post-writing stage, especially the revising and the editing processes. In the post-implementation period, the impact of the project on the learners' writing process was assessed and they reflected about it.

In the project, the teacher-researcher instructed students on process writing and on the technical management of the learning object tool: PRWRITE. In addition, the teacher-researcher followed-up on and provided feedback to students about their writing process. Finally, the teacher observed, analyzed, and interpreted students' tasks to collect data on their possible progress in their post-writing process. 
TABLE 1

ACTIVITIES AND PRWRITE LOS IMPLEMENTED

\begin{tabular}{|l|l|l|}
\hline Stage & Activities & PRWRITE LOs Use \\
\hline Pre-implementation & Instruct in narrative rhetoric & \\
\cline { 2 - 4 } & Instruct in the writing process and VLO use & PRWRITE 1 \\
\hline While-implementation & Instruct in Post-writing process & PRWRITE 2 \\
\cline { 2 - 4 } & Task No 1 Writing a story & \\
\cline { 2 - 4 } & Instruct in revising strategies & PRWRITE 3 \\
\cline { 2 - 4 } & Task No 2 Revising my story and reflecting & \\
\cline { 2 - 4 } & Task No 3 Peer-revision and Peer-feedback & PRWRITE 4 \\
\cline { 2 - 4 } & Task No 4 Editing my story & \\
\cline { 2 - 4 } & Teacher's revision and feedback & \\
\cline { 2 - 4 } & Task No 5 Publishing my story & \\
\hline & Task No 6 Reflect about the writing process & \\
\hline & Provide feedback about the writing process & \\
\hline
\end{tabular}

- Pre-implementation: in this stage, learners were trained in narrative rhetoric. They analyzed a story and described its structure (beginning, conflict, and development). In a different session, learners were trained in process writing and the steps for writing. After, students had loop training in how to use PRWRITE LOs when learning about the writing process.

- While-implementation: in this stage learners worked on five tasks and used three more PRWRITE LOs; four of the tasks were done autonomously in virtual asynchronous sessions. The first task involved writing a story on a selfchosen topic following the structure for a narrative. After that, learners used a PRWRITE LO to be trained in two revising strategies (symbol correction and comment correction). That second task on self-revision took the students longer than two hours as it was their first experience using the strategies and analyzing their own compositions for errors.

In the third task, students provided one of their classmates with peer-feedback, employing the same revision strategies from the self-revision process. In this activity learners showed they had good enough management of the use of revision strategies as a result of the previous self-revision experience. Task four was directed toward the editing of their own drafts based on the necessary adjustments that came up in the self-revision and the peer-revision processes. After having a clean draft, the teacher-researcher proceeded to revise students' stories and provided written and oral feedback. Learners showed a positive attitude toward the teacher's oral feedback, and they felt confident to ask questions and discuss possibilities for considering revising their stories. Finally, learners published their stories to accomplish the fifth task (Caro, 2014).

- Post-implementation: during this stage, learners were encouraged to develop a sixth task in which they reflected about their own writing process and showed to their peers their portfolios with the work from each task of the process. They analyzed the artifacts and shared their perceptions with their classmates. Although most of the comments were directed to highlight positive aspects of the learning process, some of them reflected about what else they could have done to produce even better products. Finally, learners completed the survey (Appendix C).

\section{Data ANALYSIS AND DisCUSSION}

Implementing PWA and PRWRITE LOs with 14 adult L2 learners showed to positively impact learners' post-writing difficulties when writing short narrative compositions. A Grounded Theory method (Corbin \& Strauss, 2008) was implemented during the data analysis process and as a result, a core category with two categories emerged (Table 2). 
TABLE 2

RESEARCH CATEGORIES AND SUB-CATEGORIES

\begin{tabular}{|l|l|l|}
\hline Core category & Categories & Sub-categories \\
\hline $\begin{array}{l}\text { Improvement of post- } \\
\text { writing by means of } \\
\text { applicable designed LOs }\end{array}$ & $\begin{array}{l}\text { Improvement in learners' post-writing skill } \\
\text { awareness }\end{array}$ & Improvement in the confidence when writing \\
\cline { 2 - 3 } & $\begin{array}{l}\text { Finding an applicable support source to scaffold } \\
\text { writing }\end{array}$ & $\begin{array}{l}\text { Improvement in mechanics, grammatical competence } \\
\text { and rhetorical structure }\end{array}$ \\
\cline { 2 - 3 } & & Applicability of PRWRITE LO \\
\hline
\end{tabular}

Results showed that the process of raising awareness of the post-writing skill was possible through the improvement in 1) learners' confidence in writing; 2) learners' use of writing strategies; and 3) mechanics, grammatical competence, and narrative as a rhetoric structure.

\section{Improvement in Learners' Post-Writing Skill Awareness}

Strategies like self-revision, peer-revision, and group-revision provided learners with tools that fostered consciousness about their autonomous actions (Benson, 2001, p. 15; Cook, 2008 in Caro, 2014). This kind of writing process development encouraged learners to assume the role of the writer having purposefully in mind an intended reader, which is identified as audience awareness (Han, 2017).

\section{Improvement in the Confidence When Writing.}

Results demonstrated that the PWA positively influenced learners' self-confidence and reduced their anxiety when writing, since it clearly stated the process and the goals students were expected to achieve in their compositions at each stage. Consequently, learners became more confident on how to write.

Having open access to PRWRITE LOs, specially designed to introduce the PWA, helped students remember the goal at each stage. In the post-writing stage, learners were able to pass from one stage to the other after experiencing a practice on strategies in the LO. After practicing how to identify errors in written samples, learners were able to selfrevise their narrative stories with successful results (Caro, 2014). Evidence of that influence from the learners' point of view can be read in the following excerpt:

Excerpt 1: ... before it was difficult for me to start elaborating a writing since I didn't know where to start. With the class writing methods revised, it has been easier for me and my compositions are better structured. (S:JZ) [Author's transcription]

The revision process also influenced learners' affective factors since they had never experienced self-revision and peer-revision practices before. After employing those revising strategies, learners expressed their positive attitudes about the suggested corrections.

Excerpt 2: I read my classmate's comments and I tried to improve in the aspects that based on mine and my classmates' criteria I had to improve. I mean, to work on the suggested corrections. (S: GT) [Author's transcription]

The participant found his classmate's suggestions useful in revising his composition during the peer-feedback stage.

\section{Improvement in the Use of Writing Strategies}

Writing as a process offers strategies to be developed in each one of the writing stages, and learners are meant to discover which ones work best for them (Brown, 2001). Since this study was focused on the post-writing process, the strategies implemented were related to the stages of revision and editing. Learners found valuable the use of strategies like self-revising, peer-revising, group-revising and self-editing. They changed their pre-conception of writing revision: before the study learners believed that the teacher was the only person in charge of providing feedback; after the implementation learners found out that they were able to self- and peer and group-revise the class writing compositions. One of the students commented on this in the survey administered.

Excerpt 3: ... before I used to write my story and I didn't know if it was well structured or coherent, I expected the teacher to correct my writing but now it is possible to self-correct my story before handing in it. (S:JT) [Author's transcription]

In general terms, learners found that they could apply the strategies they had developed in the PWA to writing assignments in other subjects.

\section{Improvement in Mechanics, Grammatical Competence, and Rhetorical Structure.}

In the post-writing stages of the PWA, the teacher's main role was "to help students develop strategies for revising: adding, deleting, modifying, and rearranging ideas" (Silva, 1993, p.662), which corresponds to content, "and for editing: attending to vocabulary, sentence structure, grammar and mechanics" (Silva, 1993, p.665), which respond to form in writing. Learners in this study showed improvement in both content and form in their narrative compositions (Caro, 2014). 
TABLE 3

ANALYSIS OF GRAMMAR, MECHANICS AND VOCABULARY ON STUDENTS’ ARTIFACTS

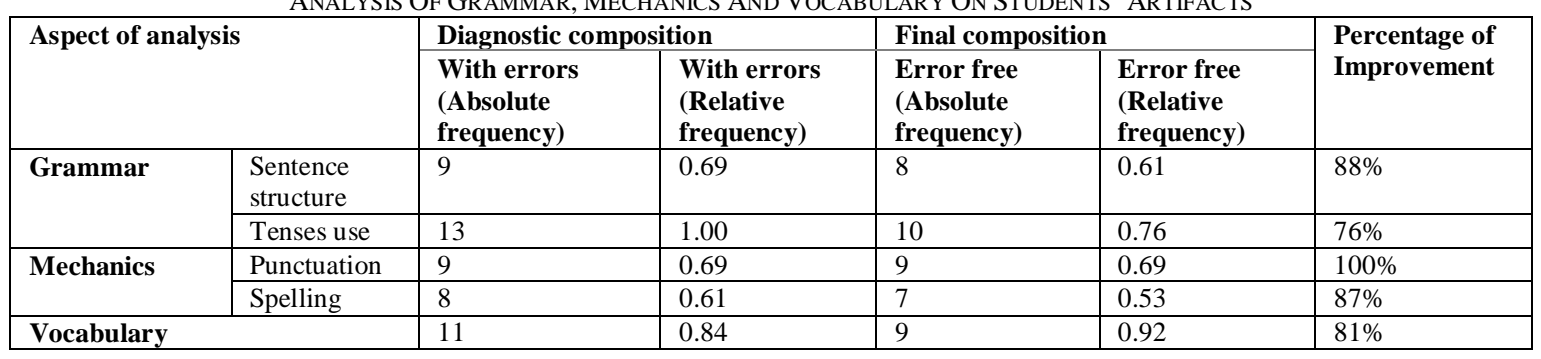

Impact on form: Grammatical competence, mechanics and vocabulary. The results obtained from the analysis of the learners' compositions after the implementation (Table 3) demonstrate that eight of the nine students (88\%) who evinced difficulties at the beginning improved in sentence structure and ten of the thirteen (76\%), improved in the use of correct tenses. Learners' improvement is attributed to the revising and editing strategies worked during the process of post-writing, and to practice exercises completed on identification of mistakes in sentence level.

Excerpt 4: ... I have improved on the correct use of grammar tenses and I have focused more on it. (S: LB). (S: GT) [Author's transcription]

Excerpt 5: ...I improved on the form of writing sentences, on word order and spelling, too (S:PO) [Author's transcription]

Regarding mechanics, in the diagnostic composition, students committed errors in punctuation and spelling because they tended to overuse commas in order to separate ideas, instead of periods. Based on the comparison with the final narrative composition (Table 3), all of students (100\%) improved in the use of punctuation marks and most of them (87\%) showed complete improvement in spelling (Caro, 2014).

Finally, regarding the use of vocabulary, the checklist analysis (Table 3) showed that almost all students (11 over 13) demonstrated to have 3- 15 mistakes in word choice in their diagnostic narrative compositions. Results from the final composition indicate that most of students $(81 \%)$ improved in the identification of appropriate vocabulary. The 2 students (19\%) who did not improve totally and still presented mistakes in the use of vocabulary, had between 1 and 5 vocabulary mistakes which also shows partial improvement.

Impact on content: Narrative rhetoric. In this study, students were stimulated to write their narrative compositions based on their own topic choices. They were trained in how to structure a short narrative composition, but they were not limited in what to write about. In this case, learners could explore their own ideas and use the L2 (English) to convey their messages.

In terms of content, aspects such as coherence and narrative rhetorical structure were worked by developing learners' narrative compositions. Learners could not only identify the rhetorical organization of a narrative composition, but they could also appropriately apply it to their own written story. Results indicate that all students (100\%) who found it difficult to write an appropriate beginning, conflict, and development of a story improved in it. They were able to include time, characters, setting, and a starting point of the story, conflict and resolution of the conflict in their narrative structures. The following table illustrates the improvement:

TABLE 4

ANALYSIS OF CONTENT ON STUDENTS' ARTIFACTS

\begin{tabular}{|l|l|l|l|l|l|l|}
\hline \multirow{2}{*}{ Aspect of analysis } & \multicolumn{2}{|l|}{ Diagnostic composition } & Final composition & $\begin{array}{l}\text { Improvement } \\
\text { Percentages }\end{array}$ \\
\cline { 3 - 7 } \multicolumn{2}{|c|}{} & $\begin{array}{l}\text { With errors } \\
\text { (Absolute } \\
\text { frequency) }\end{array}$ & $\begin{array}{l}\text { With errors } \\
\text { (Relative } \\
\text { frequency) }\end{array}$ & $\begin{array}{l}\text { Error free } \\
\text { (Absolute } \\
\text { frequency) }\end{array}$ & $\begin{array}{l}\text { Error free } \\
\text { (Relative } \\
\text { frequency) }\end{array}$ & \\
\hline \multirow{3}{*}{ Content } & Beginning & 13 & 1.00 & 13 & 1.0 & $100 \%$ \\
\cline { 2 - 7 } & Conflict & 6 & 0.46 & 6 & 0.46 & $100 \%$ \\
\cline { 2 - 7 } & Development & 7 & 0.53 & 7 & 0.53 & $100 \%$ \\
\hline
\end{tabular}

Learners also demonstrated their improvement and awareness of the rhetorical narrative structure incorporation in their compositions. The main features to structure the story were a beginning, a conflict and a development, and through their inclusion learners demonstrated that their narratives followed a logical sequence (Caro, 2014).

Excerpt 6: ... a chronological sense is given to the ideas and there is a better connection with the management of the narrative time (S:PA) [Author's transcription]

Excerpt 7: ...I could recognize a text structure in my own compositions (S:GT) [Author's transcription]

Figure 1 illustrates one of the student's artifacts and his usage of self-revising strategies. Learners used codes to categorize the mistakes of form and comments to suggest improvements regarding content. 


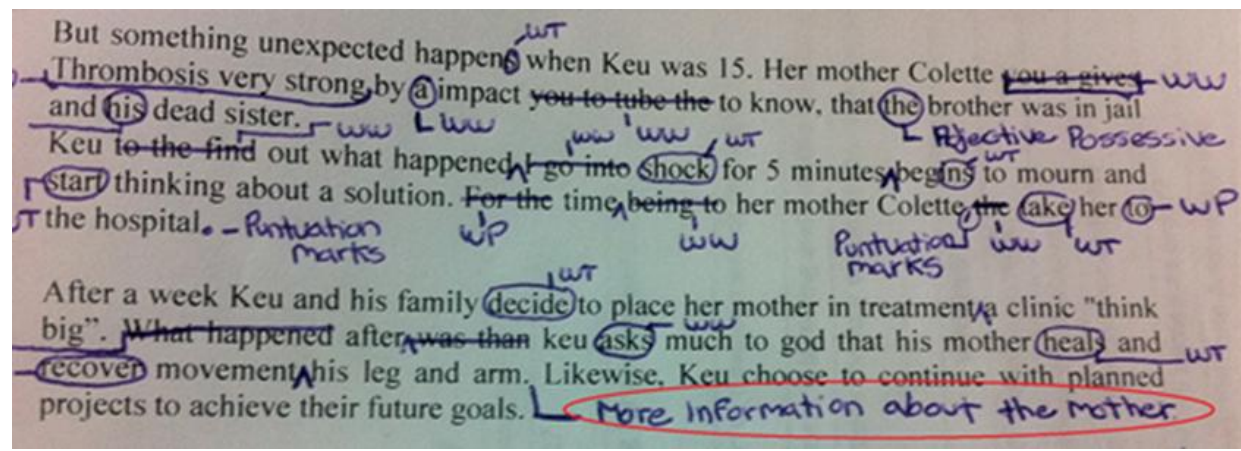

Figure 1 Self-revision Artifact. (S:CM)

The use of strategies for improving coherence helped most of students to progress in the organization of ideas; hence their paragraphs were better structured. All students (100\%), who presented difficulties when structuring paragraphs in the diagnostic, showed improvement by the end of the study. This was identified in the sequence and connection among ideas in a paragraph and the division of paragraphs in the text.

TABLE 5

ANALYSIS OF PARAGRAPH STRUCTURE ON STUDENTS' ARTIFACTS

\begin{tabular}{|c|c|c|c|c|c|c|}
\hline \multirow{3}{*}{\multicolumn{2}{|c|}{ Aspect of analysis }} & \multirow{2}{*}{\multicolumn{2}{|c|}{ Diagnostic composition }} & \multirow{2}{*}{\multicolumn{2}{|c|}{ Final composition }} & \multirow{3}{*}{$\begin{array}{l}\text { Improvement } \\
\text { Percentages }\end{array}$} \\
\hline & & & & & & \\
\hline & & $\begin{array}{l}\text { With errors } \\
\text { (Absolute } \\
\text { frequency) }\end{array}$ & $\begin{array}{l}\text { With errors } \\
\text { (Relative } \\
\text { frequency) }\end{array}$ & $\begin{array}{l}\text { Error free } \\
\text { (Absolute } \\
\text { frequency) }\end{array}$ & $\begin{array}{l}\text { Error free } \\
\text { (Relative } \\
\text { frequency) }\end{array}$ & \\
\hline $\begin{array}{l}\text { Paragraph } \\
\text { structure }\end{array}$ & $\begin{array}{l}\text { Sequence of } \\
\text { ideas }\end{array}$ & 7 & 0.53 & 7 & 0.53 & $100 \%$ \\
\hline
\end{tabular}

Finding an applicable support source to scaffold writing.

In this study, PRWRITE LOs were used to support students' narrative process of writing. In the implementation of PRWRITE LOs students did not show any technical problems with their use. It proves that the training done on the tool management represented a meaningful part for learners to succeed in its use. Learners expressed to have benefitted from the use of PRWRITE because they found it functional to improve their writing.

\section{Applicability of the PRWRITE LOs.}

PRWRITE LOs were designed by the teacher researcher based on the learner's English level, their writing learning needs and their learning styles (Kamariah et al., 2018). Those adjustments permitted students to benefit in different ways.

PRWRITE LOs: learner's insights. According to the findings, PRWRITE LOs were an innovative tool that facilitated student's learning because those helped them to clarify and understand important concepts for the process of writing. In addition, PRWRITE LOs supported students writing learning process since they provided instruction and a clear sequence on how to write. Learners highlighted PRWRITE aspects such as its interactivity and practicality, which made it a motivating and interesting tool to learn.

PRWRITE LOs were also interesting, interactive and innovative ways of learning and making learning easier. These are some comments made by students about their perception on the usefulness of PRWRITE LOs.

Excerpt 8: ...we have been given a guide to use better a methodology for writing, so that everything is clearer and consistent (S:LR) [Author's transcription]

Excerpt 9: ... [the PRWRITE learning object] is something that innovates our writing process, giving an extra motivation (S:WR) [Author's transcription]

Excerpt 10: ... [the PRWRITE learning object] is something interactive and new (S: MV) [Author's transcription]

Excerpt 11: ... [the PRWRITE learning objects] are tools that facilitate the learning. (S:JR) [Author's transcription]

\section{Awareness on autonomy in PRWRITE LOs.}

In the process of learning to write, autonomy is fostered and becomes an engaging process when learners have clarity over the goals to be achieved through the writing task. Those tasks goals become personal goals when the learner finds at each stage new challenges and new opportunities for improving. Improvement in the post-writing stages of revision and edition goes hand in hand with the learner awareness about the required aspects to improve. In this study, students were trained in revision and edition strategies by using PRWRITE LOs, which not only encouraged awareness on possible aspects for improving their narrative compositions, but also provided to be a useful tool for learners to work autonomously their writing. PRWRITE LOs contributed to rising students' autonomy by providing them with a structured methodology on how to develop their narrative compositions, consequently the expected goal at each stage was clearly understood.

Excerpt 12: these virtual objects have helped us to discipline our way to do things, well done and in less time. (S:WR) [Author's transcription]

It is important to consider that most of the tasks in this study were carried out autonomously by students with the guidance of PRWRITE LOs. That confirms that students were required to be autonomous and to actively participate in 
the writing process. At each writing stage, the learners' products evinced that the PRWRITE LOs could appropriately guide them in the process of achieving each writing goal. One of the advantages of using LOs remained on its accessibility because at each stage of the process students could go back and clarify what the stage was about, its importance in the writing process, how it could be achieved, and what was expected (Caro, 2014).

That advantageous access to the tool at any moment of the process, fostered learners' autonomy, since learners independently accessed to it according to their individual learning needs and purposes. Figure 2 illustrates part of a PRWRITE LO used to train students in the PWA. This part included the definition and importance of the revising stage, the expected actions and a reflection exercise to enhance comprehension on self-revision.

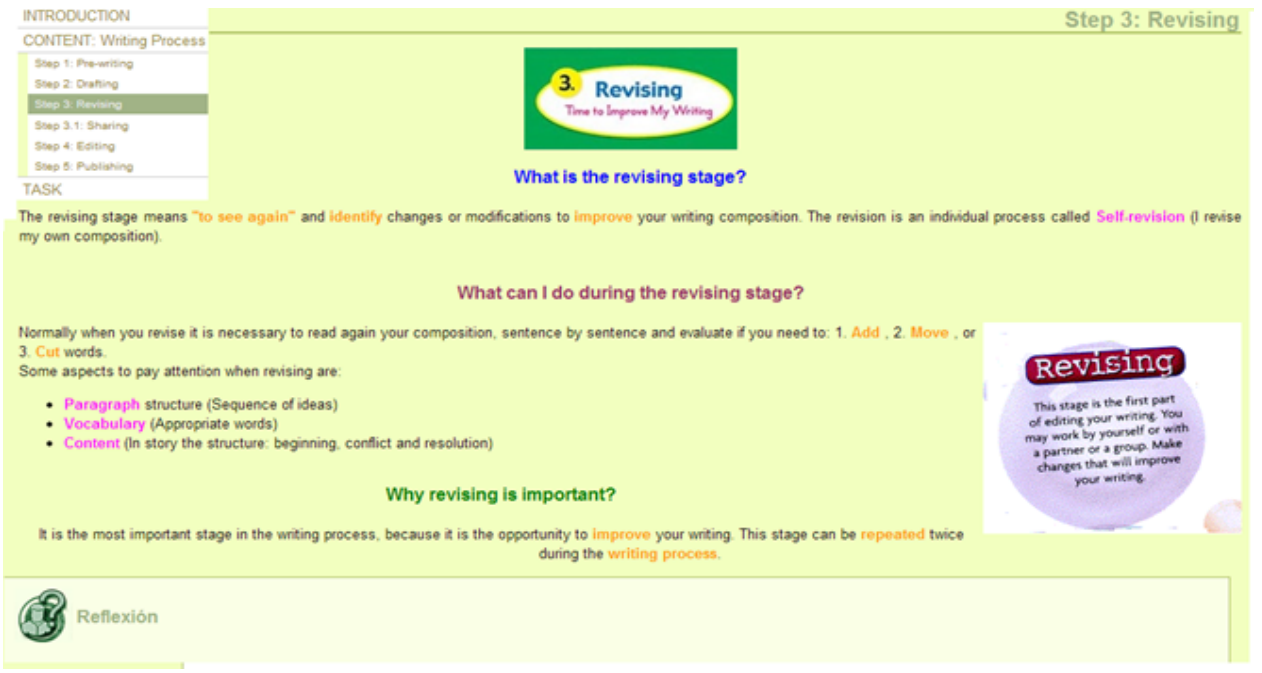

Figure 2 PRWRITE learning object sample

\section{CONCLUSIONS}

This action research study states a new alternative for developing L2 writing skill in the language teaching-learning field. This is a way to tackle student's post writing difficulties by engaging learners in a process in which they autonomously experience strategies to become better writers (Asri, 2015; Raoofi, Binandeh, \& Rahmani, 2017). The findings of this study confirm what other studies inform about the power of the PWA for developing the writing skill (Vijaya \& Shahin, 2016). Learners in this study increased their confidence when writing and their improvement in the proper use of grammar, vocabulary, narrative rhetorical structure and paragraph structure. In addition, learners showed a better use of writing strategies, which also caused an increase of awareness on how their autonomous actions benefited their own improvements. Further research can be directed to the influence or motivation in learners' topics choices for writing. The influence of the PWA could also be explored in writing tasks set for academic courses different from English as a foreign language.

Results also show that PRWRITE LOs positively influenced learner's motivation and engagement in the autonomous development of writing tasks, which is consistent with findings by Suriaman, Rahman and Noni (2018). The tool was mainly applicable because it provided instruction and a clear sequence on how to write, which helped learners clarify and understand concepts about the writing process. Other technological tools for scaffolding writing in order to verify different ways of motivating and fostering language learning could be explored. Furthermore, LOs impact on the development or improvement of other language skills could be revised.

In relation to language teaching, this study invites teachers to get involved in designing applicable tools that not only fit learners' needs and goals (Kamariah et al., 2018), but also that motivate and engage them in an improving process, which cyclically fosters learning awareness. 
APPENDiX A. CHECKLIST

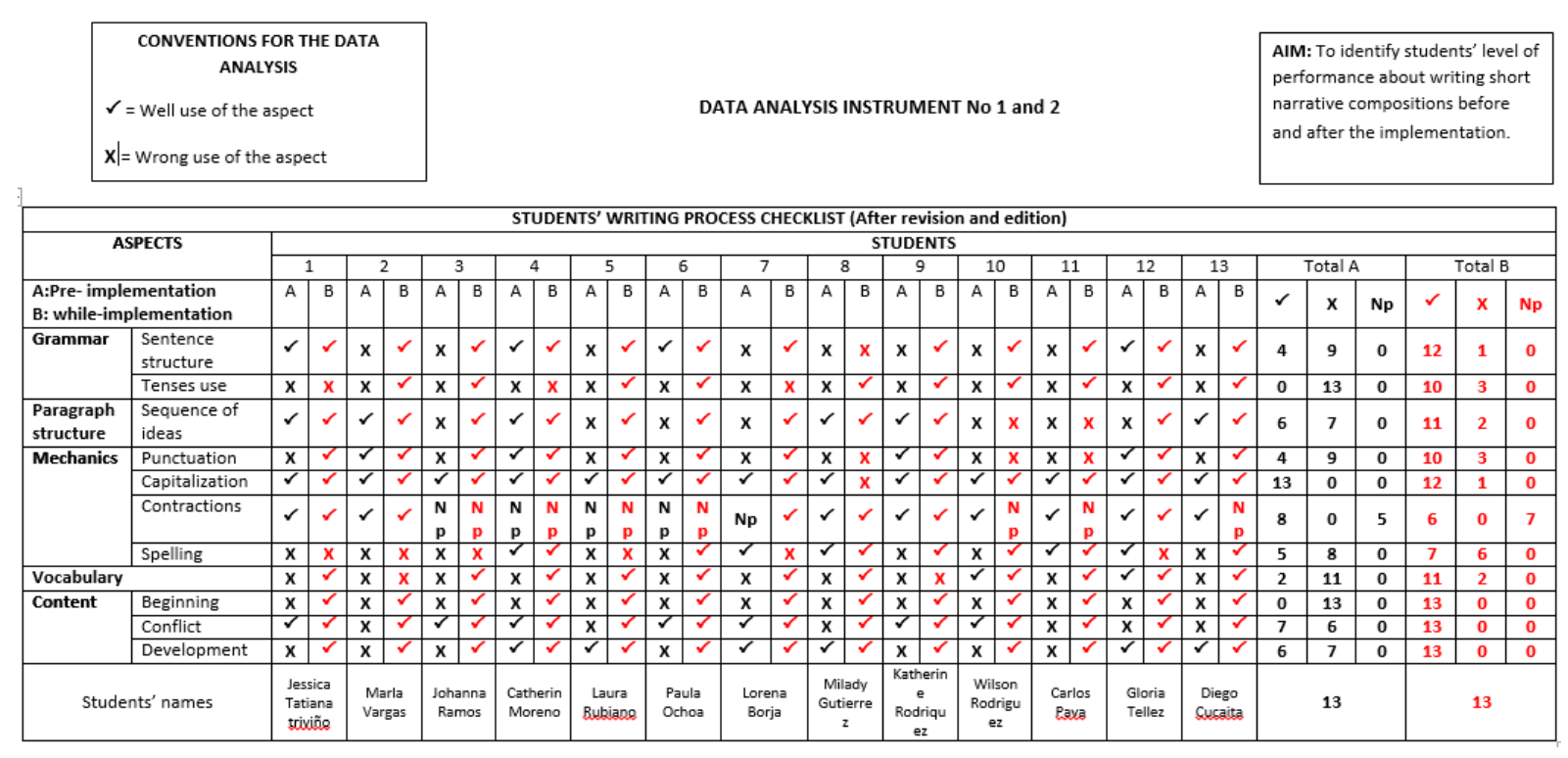

\section{Appendix B. Qualitative Analysis of the CheCKList Results}

\begin{tabular}{|c|c|c|c|c|c|c|}
\hline \multirow{2}{*}{\multicolumn{2}{|c|}{ ASPECTS }} & \multicolumn{5}{|c|}{ INSTRUMENT No 1 QUALITATIVE ANALYSIS } \\
\hline & & \multicolumn{3}{|c|}{ Total A } & \multicolumn{2}{|c|}{ Interpretations } \\
\hline \multicolumn{2}{|c|}{$\begin{array}{l}\text { A:Pre- implementation } \\
\text { B: while-implementation }\end{array}$} & $\checkmark$ & $\mathrm{x}$ & $\begin{array}{l}\mathrm{N} \\
\mathrm{p} \\
\end{array}$ & Difficulties & Strengths \\
\hline \multirow[t]{2}{*}{ Grammar } & $\begin{array}{l}\text { Sentence } \\
\text { structure }\end{array}$ & 4 & 9 & 0 & $\begin{array}{l}\text { Most of the students (69\%) presented difficulties when structuring } \\
\text { sentences; it was mainly evinced in the sentences word order and the } \\
\text { length of the sentences. }\end{array}$ & \\
\hline & \begin{tabular}{|l|} 
Tenses use \\
\end{tabular} & 0 & 13 & 0 & $\begin{array}{l}\text { All students (100\%) presented difficulties on the appropriate use of } \\
\text { tenses based on their }\end{array}$ & \\
\hline $\begin{array}{l}\text { Paragraph } \\
\text { structure }\end{array}$ & $\begin{array}{l}\text { Sequence of } \\
\text { ideas }\end{array}$ & 6 & 7 & 0 & $\begin{array}{l}\text { More than half of the group (53\%) presented difficulties on sequencing } \\
\text { the ideas. It was evinced }\end{array}$ & \\
\hline \multirow[t]{4}{*}{ Mechanics } & Punctuation & 4 & 9 & 0 & $\begin{array}{l}\text { The majority of the students (69\%) presented difficulties when using } \\
\text { punctuation marks. Most of them tended to overuse commas in order to } \\
\text { separate ideas, instead of periods. }\end{array}$ & \\
\hline & Capitalization & 13 & 0 & 0 & & $\begin{array}{c}\text { All students (100\%) demonstrated a proper use of capitalization } \\
\text { through their stories. }\end{array}$ \\
\hline & Contractions & 8 & 0 & 5 & & $\begin{array}{l}\text { A large quantity of students presented an appropriate use of } \\
\text { contractions throughout their compositions. The rest of the group } \\
\text { did not include any contractions and any of the students use them } \\
\text { incorrectly. }\end{array}$ \\
\hline & Spelling & 5 & 8 & 0 & 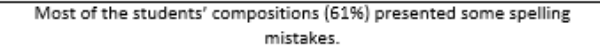 & \\
\hline \multicolumn{2}{|l|}{ Vocabulary } & 2 & 11 & 0 & $\begin{array}{l}\text { Almost all the students (84\%) presented between } 3-15 \text { wrong vocabulary } \\
\text { mistakes. The latter evinces learners' difficulties to identify the } \\
\text { appropriate words according to the context. }\end{array}$ & \\
\hline \multirow[t]{3}{*}{ Content } & Beginning & 0 & 13 & 0 & $\begin{array}{l}\text { All students (100\%) found difficult to write an appropriate beginning of } \\
\text { the story, since the story rhetoric structure suggests including aspects } \\
\text { like: Time, characters, setting and a starting point of the story. }\end{array}$ & \\
\hline & Conflict & 7 & 6 & 0 & & $\begin{array}{l}\text { More than the half of the learners (53\%) showed a proper } \\
\text { development of the story, by including how the conflict started } \\
\text { and describing what happened with it. }\end{array}$ \\
\hline & Development & 6 & 7 & 0 & $\begin{array}{l}\text { More than the half of the learners (53\%) demonstrated difficulties when } \\
\text { structuring the development of the story. The latter was evinced in the } \\
\text { lack of resolution of the conflict presented, or the weak description on }\end{array}$ & \\
\hline
\end{tabular}

\section{APPENDIX C. SURVEY}

Dear student,

This survey aims to collect confidential and anonymous information about your experience with PRWRITE learning objects. Data collected is only for academic and research purposes. It will take you 15 minutes to complete the survey. Thanks for your participation.

- Research Question: How does the implementation of process writing approach through PRWRITE learning objects impact learner's short narrative composition?

Survey Questions:

1. What do you do after you finish a writing composition?

2. Describe the changes you have done to your compositions. If any. 
3. What do you do after receiving feedback on your drafts?

4. What aspects have you improved about your writing skill? If any.

5. Number from 1 to 4 the following aspects being 1 what you have improved the most when writing compositions and 4 the one you have improved the least.

Vocabulary

Content

Sentence structure

Paragraphs structure

6. Did you find useful the implementation of PRWRITE learning object for your writing improvement?

a. Yes

b. $\quad$ No

Why?

7. What did you learn about your writing process from the use of PRWRITE learning object?

\section{REFERENCES}

[1] Ariza, A. (2005). The process-writing approach, an alternative to guide students' compositions. PROFILE: Issues in Teachers ' Professional Development, 6, 37-46.

[2] Asri, Y. (2015). The Impact of the Application of Paired- storytelling Technique and Personality Type on Creative Writing, 6(2), 302-307.

[3] Baroudy, I. (2008). Process Writing: Successful and unsuccessful writers; Discovering writing behaviors. Universidad de Murcia. 8(2): 43-63.

[4] Behar, P., Frozi, A. \& Bernardi, M. (2008). Virtual Learning Communities: A learning object integrated into an e-learning platform 281. 163-174. http://www.springerlink.com/content/e23h8034n460k236/ (accessed 16/5/2018).

[5] Benson, P. (2001). Teaching and researching autonomy in language learning. London: Longman.

[6] Brown, H. D. (2001). Teaching by principles: An interactive approach to language pedagogy (2nd ed.). New York: Longman.

[7] Burns, A. (2010). Doing Action Research. New York: Taylor and Francis E-library.

[8] Caro, M. (2014). Impact of Implementing Exe Virtual Learning Objects on Autonomous Learning in the Paragraph Writing of A2 Learners. Intellectum Repository.

[9] Castellano, J. (2016). Advanced Media English- A Modern PrOCALL Course. Computer-Assisted Language LearningElectronic Journal. 17.15, 52 - 66.

[10] Chapelle, C. (2008). Tips for teaching with CALL: Practical approaches to Computer-Assisted Language Learning. New York: Pearson Education, Inc

[11] Cook, V. J. (2008). Second language learning and language teaching. London: Hodder Education.

[12] Corbin, J. \& Strauss, A. (2008). Basics of Qualitative Research. (3rd Ed). USA: Publications Inc.

[13] Díaz, D (2010). Análisis y construcción de un objeto virtual de aprendizaje (ova) con Tecnología en 3d que facilite el conocimiento de la estructura electrónica de algunos elementos de la tabla periódica. Universidad Sergio Arboleda. Escuela de Ingeniería. Retrieved http://ingenierias.usergioarboleda.edu.co/index.php?option=com_jresearch\&view=thesis\&task=show\&id=9 from: $12 / 5 / 2014)$.

[14] Dörnyei, Z. (1998). Motivation in second and foreign language learning. Language Teaching 31. 117-135.

[15] Ellis, R. (2003). Task-based language teaching and learning. Oxford: Oxford University Press.

[16] Fallon, G., Janson, A., \& Janson, R. (2010). Learning objects and the development of students' key competencies: A New Zealand school experience. Australasian Journal of Educational Technology 26.5, 626-642.

[17] Flower, L., \& Hayes, J. R. (1981). A cognitive process theory of writing. College Composition and Communication. 32.4, 365387.

[18] Han, C. (2017). The Effectiveness of Application of Writing Strategies in Writing Instruction. Journal of Language Teaching \& Research 8.2, 355-361. https://doi.org/http://dx.doi.org/10.17507/jltr.0802.19.

[19] Kamariah, A., Husain, D., Atmowardoyo, H., \& Salija, K. (2018). Developing Authentic-based Instructional Materials for Writing Skill 9.3, 591-599.

[20] Leal, D. (2008). Iniciativa colombiana de objetos de aprendizaje: situación actual y potencial para el futuro. Apertura, 8(8), 7685. Retrieved from http://www.udgvirtual.udg.mx/apertura/index.php/apertura/article/viewFile/1193/677 (accessed 20/11/2017).

[21] Lo, J., \& Hyland, F. (2007). Enhancing Students' Engagement and Motivation in Writing. Journal of Second Language Writing 16. 219-237.

[22] Masaeli, N., \& Chalak, A. (2016). The Effect of Employing Electronic Portfolio on Iranian EFL Learners' Writing Skill. Journal of Language Teaching \& Research 7.4, 746-751. Retrieved from http://www.academypublication.com/ojs/index.php/jltr/article/view/jltr0704746751 (accessed 16/5/2018). 
[23] Merriam, S. B. (2001). Andragogy and self-directed learning: pillars of adult learning theory. New Directions for Adult and Continuing Education 89, 3-13.

[24] Onozawa, C. (2010). A Study of the Process Writing Approach: A suggestion for an eclectic writing approach. ELT Journal 58, 327-335.

[25] Raimes, A. (1983). Techniques in teaching writing. New York: Oxford University Press.

[26] Ramirez, D. (2009, Marzo). Objetos virtuales de aprendizaje en e-learning 2.0. Paper presented at. XVI Congreso Internacional Sobre Educación Electrónica, Móvil, Virtual y a Distancia. "Inclusión social y globalización. Conference proceedings, Bogota, Colombia. Retrieved from http://wiki.nomono.co/images/8/8d/13114213--Objetos-virtuales-de-aprendizaje-en-elerning-20David-Ramirez.pdf (accessed 22/11/2017).

[27] Raoofi, S., Binandeh, M., \& Rahmani, S. (2017). An Investigation into Writing Strategies and Writing Proficiency of University Students. Journal of Language Teaching and Research, 8(1), 191-198.

[28] Silva, T. (1993). Toward an understanding of the distinct nature of the 12 writing the ESL research and its implications. TESOL Quarterly 27, 665-77.

[29] Smith, N. (2005). Learning Objects, Learning Object Repositories and Learning Theory: Preliminary best practices for online courses. Journal of Knowledge and Learning Objects. 1: 217- 228.

[30] Suriaman, A., \& Noni, N. (2018). Developing Web-based English Instructional Material Oriented to Promote Independent Learning at Indonesian University Context 9.2, 336-345.

[31] Tang, S. (2016). Digital Storytelling Approach in a Multimedia Feature Writing Course. Journal of Language Teaching and Research. 7.3, 572-578.

[32] Vijaya K. S., \& Shahin S. A. (2016). Integration of multimedia for teaching writing skills. Computer-Assisted Language Learning- Electronic Journal. 17.30, 57 - 86.

[33] Watson, J (2010). A case study: Developing learning objects with an explicit learning design. Electronic Journal of e-Learning, $8.1,41-50$.

[34] Wiley, D. (2000). Connecting learning objects to instructional design theory: A definition, a metaphor, and a taxonomy. In D. A. Wiley (Ed.), The Instructional Use of Learning Objects: Online Version. Retrieved from: http://reusability.org/read/chapters/wiley.doc (accessed 22/4/2012).

[35] Zamel, V. (1983). The Composing Processes of Advanced ESL Students: Six Case Studies. In Hyland, K. (2002). Teaching and researching writing. England: Pearson Education Limited.

[36] Zuniga, G., \& Macias, D. (2006). Refining students' academic writing skills in an undergraduate foreign language teaching program. Ikala, 11.17, 310-336.

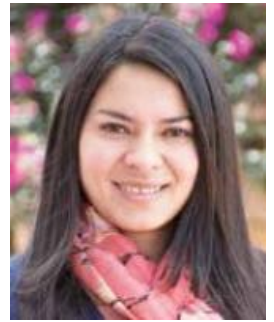

María C. Caro was born in Bogotá, Colombia on April 24, 1986. She is a professor at Universidad de La Sabana. She holds and MA in English Language Teaching - Autonomous Learning Environments from Universidad de La Sabana in 2014 and a BA in English and Spanish Language Teaching from Universidad Pedagógica Nacional in 2010 Bogotá, Colombia. Her research interests include technology integrated to language teaching, design of materials for teaching languages and autonomy fosterage. Now she teaches English in the undergraduate program and the Autonomous Learning Environments course in the Master program. She also works as a coordinator of the area of support for English learning in the Department of Foreign Languages and Cultures.

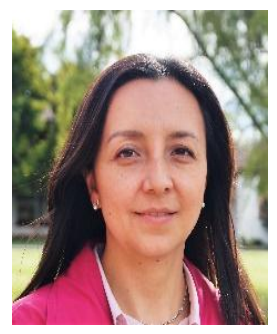

Diana A. Parra was born in Bogotá, Colombia on February 9th, 1979. She currently serves as Director of Studium, the Language Research and Resource Center -at Universidad de La Sabana. She holds an MA in English Language Teaching- Autonomous Learning Environments from Universidad de La Sabana and a BA in Philology and Languages from Universidad Nacional de Colombia. Her research interests include virtual and hybrid learning, innovation in education, and instructional design for self-directed learning. 